\title{
THE EFFECTS OF HOSPITALISATION ON CHILDREN: A REVIEW
}

\author{
M Bonn
}

\begin{abstract}
The ain of this article is to present a selective review of the research on children's psychological responses to hospitalisation. Children vary in their capacities to cope with the stress of hospitalisation. A significant proportion of them, however, suffer from some degree of emotional disturbance due to the experience. Prolonged and repeated hospitalisation increases the chance of later problems. The separation of the child from familiar figures during admission may be the cause of some of the emotional upset. Younger children, especially those between the ages of 6 months and 4 years are most vulnerable. Individual factors such as the children's temperament and intelligence contribute to their style of coping and thus may influence both the short term and long term effects of hospitalisation. Children who take an active coping role are more cooperative with hospital staff and show less disturbance after discharge. The preparation of children for the experience of hospitalisation has proven to be very effective in reducing their emotional distress during admission.
\end{abstract}

\section{OPSOMMING}

Die doel van hierdie artikel is om 'n selektiewe resensie te gee van die navorsing op die sielkundige reaksie van kinders op hospitalisering. Die vermoë van kinders om die spanning van hospitalisering te hanteer verskil, nogtans ondergaan 'n aansienlike persentasie 'n mate van emosionele ontwrigting weens die ondervinding. Lang en herhaalde hospitalisering verhoog die kanse van latere probleme. Die skeiding van die kind van bekende figure tydens admissie kan die moontlike oorsaak van emosionele ontwrigting wees. Jonger kinders, veral die tussen die ouderdom van 6 maande en 4 jaar, is die mees kwesbaar. Individuele eienskappe soos die temperament en intelligensie van die kind dra by tot die manier waarop die kind hospitalisering hanteer en kan in beide die kort en lang termyn invloed van die ondervinding 'n rol speel. Kinders wat aktief probeer on die ondervinding te verwerk, werk beter met die hospitaal personeel saam en toon minder ontwrigting na ontslag. Die voorbereiding van kinders vir die ondervinding in die hospitaal blyk baie effektief te wees in die vermindering van emosionele angs tydens hospitalisering.

For quite some time doctors, nurses and parents have been concerned with the emotional stress caused by hospitalisation in the life of children. Some children crumble at the divorce of their parents, some at moving house and leaving their friends and many fail to come to terms with going to hospital. This selective review will examine evidence concerning both short-term and long-term effects of hospitalisation, individual differences in response to hospitalisation, different styles of coping with medical treatment and hospitalisation and techniques used to prepare children for the experience of hospitalisation.

Does hospitalisation harm children?

Bowlby (1951) was probably the first to warn us that hospitalisation could scar children for life, mainly because of the separation from mothers which admission to hospital required at the time. The child's distress according to Bowlby followed a common sequence: first protest, then despair and lastly detachment. The writings and views of Bowlby and Robertson (1958) were most influential in the drafting of the British Platt Report (British Ministry of Health, 1959), the main recommendation of which was to advocate the provision of facilities in children's wards for the mothers of under-fives, to enable them to remain with their children.

Subsequent research has confirmed the benefit of admitting parents. Children especially under the age of 6 experience less distress when hospitalised if the mother is allowed to stay with them. Illingworth and Holt (1955) showed that children expressed lower levels of distress if parents visited daily and even less distress if they were admitted with their children. A study carried out by Brain and Maclay (1968) confirmed the above findings and showed that children who were admitted with their parents for tonsillectomy had fewer post-operative complications as well as showing better adjustment on the wards than children admitted for the same operation but without their parents.

MoGillicuddy (1976) studied the effect of rooming-in and non-rooming in on ninety children between the ages of 14 months and 4 years. The children were equally divided into three groups: rooming-in (i.e. parents staying with the child in hospital), non-rooming-in and a non-hospitalised group. All children in the first two groups were hospitalised for minor surgery. The Posthospitalisation Behaviour Questionnaire (Vernon \& Schulman, 1965) was mailed to each mother one month after the child's discharge from the hospital. McGillicuddy found that the children whose mothers had roomed-in were generally less anxious, eating better, and more outgoing and involved. Children whose mothers did not room-in demonstrated problems in the areas of separation anxiety, anxiety about sleep, aggression toward authority, and apathetic withdrawal. She also found that there were essentially no differences between the rooming-in group and the non-hospitalised group of children.

In another investigation, Couture (1976) studied the effect of rooming-in as opposed to two other limited visiting conditions: parents who visited eight or more hours per day and those who visited less than eight hours per day. All thirty one children, aged 3 years to 5 years and 11 months, were admitted for tonsillectomy and/or adenoidectomy. Each set of parents was interviewed on the day of admission and at the first and fourth weeks after discharge. Couture compared the ratings of the two post-hospitalisation interviews with that of the admission interview. He found that the children in the two limited visiting groups exhibited greater behavioural regression following discharge than the rooming-in group. Moreover, four weeks post-hospitalisation the two limited visiting groups had not returned to their pre-hospitalisation level of behaviour, whereas the rooming-in group had surpassed 
their pre-hospitalisation level. It is now widely accepted that the presence of the parent is important for the child's coping reactions in hospital and the inclusions of mothers (or/and fathers) has become part of the routine in many paediatric wards.

Are negative effects only due to separation from familiar figures or is hospitalisation intrinsically harmful?

Vernon and Schulman (1965) developed a parental questionnaire of twenty seven behavioural symptoms regarding children's behaviours following hospitalisation. They used this questionnaire to study the effects of hospital ization on post-hospital adjustment in children aged 1 month to 9 years. The authors report that hospitalization is an "upsetting experience for children in general, resulting in increased separation anxiety, sleep anxiety and aggression towards authority". However they found that these changes were not very serious and indeed $25 \%$ of the children actually showed some improvement. The results also showed that age (6 months to 4 years), length of hospitalization (two weeks or more) and socio-economic class (high) increased the child's susceptibility to hospitalization upset, while sex, prior hospitalization, degree of pain experienced during hospitalization and birth order did not show any systematic effects.

A study carried out by Davenport and Werry (1970) questioned the validity of Vernon's questionnaire. In this study the behaviour of 14.5 children, aged one to fifteen, undergoing tonsillectomy was compared to that of 145 non hospitalised children. The Posthospital Questionnaire (PHBQ) devised by Vernon et al. (1967) was used to obtain ratings of the children's behaviours. Davenport and Werry found that post-hospitalization problems were an infrequent phenomenon. There were no significant differences on any of the factors scores or on the total score between the two groups. The results lent no support to the Vernon view that a significant number of children suffer a psychological upset after hospitalisation. The differences in results from other studies supportive of the Vernon's findings may however be attributed to at least two factors: one is that the period of hospitalisation for the Davenport and Werry study (1970) was short, that is less than 48 hours, while children in other studies required longer periods of hospitalisation. The second factor is the severity of the surgery: the Davenport and Werry (1970) study only included children undergoing minor surgery.

Long term effects of hospitalization were observed by Douglas (1975) in his 26 year longitudinal study of 958 children. No distinction was made between those who had surgery and those who had not. He found that an increased risk of behavioural disturbance and scholastic and reading difficulties in adolescence were associated with one hospital admission of more than one week's duration; or repeated admissions of more than one week's duration; or repeated admissions before 5 years of age - especially between 6 months and 4 years. These "at- risk" children were observed to be more troublesome outside class, more prone to delinquency and eventually more likely to show unstable job patterns than those children not admitted to hospital during the first five years of their life. The vulnerability of children to these problems was shown to increase if they were highly dependent on their mothers and were experiencing stress at home, such as poor care or the recent birth of a sibling at the time of admission. In a similar study, Quinton and Rutter (1976) checked the hospital records of 399 ten-year old children who had been tested on a questionnaire to assess emotional and behavioural problems in school (Rutter, 1967). Their findings replicated those of Douglas (1975) in that single hospital admissions for up to a week carried no increased risk for later emotional or behavioural disturbance. However, repeated hospital admissions were associated with later disturbance, especially if the children came from deprived or disturbed families.

\section{Individual differences in response to hospitalisation}

The importance of individual factors that can influence vulnerability to stress has now gained general acceptance. Research so far has consistently shown age as being the most important variable moderating the impact of hospitalization both during the event and after the discharge. School age children, by virtue of their cognitive abilities, are more prepared to deal with the experience of hospitalisation and surgery. For example, the study by Vernon et al. (1967) showed that younger children experienced more distress during most aspects of hospitalisation and treatment. Infants from 6 months to 4 years of age were most upset by separation from their parents and their familiar surroundings. Rutter (1983) suggests that children of this age are particularly vulnerable because this is a time when selective attachments are first forming and yet children of this age are only just beginning to be able to maintain relationships during a period of separation. Katz, Kellerman and Siegel (1980) studied 115 children with cancer, aged between 1 and 18 years, undergoing hospitalization. An observational behaviour rating scale was developed to measure anxiety responses to bone marrow aspirations, to differentiate highly anxious children from children with low anxiety as measured by independent nurses' ratings. As expected, younger children displayed more behavioural anxiety than older children. The researchers subdivided the sample into three age bands: 1 to 5,6 to 10,11 to 18 years. The youngest group were the most anxious during a routine medical examination, followed by the school age group (6 to 10 ) with the adolescent showing the least anxiety (11 to 18). In addition the results showed distinctive differences between males and females, with girls being rated as more anxious than boys.
There is now considerable evidence that young children show wide individual differences in behavioural styles, that is, in the "how" of their behavioural responses to differing situations (Dunn, 1980, Keogh and Pullis, 1980). Temperament theory asserts that individuals have unique consistent behavioural styles that affect their responses to new or difficult situations. Temperament is viewed as a collection of relatively consistent, basic dispositions which underlie and modulate the expression of activity, reactivity, emotionality and sociability (Goldsmith et al., 1987). Research also suggests that children's temperament characteristics influence their behaviour in many kinds of environment and may influence the responses of others to the child (Carey, Fox and McDevitt, 1977). Thus one would expect the children's temperament to affect their response to hospitalisation. Surprisingly there has been little research on the influence of temperament on children's ability to cope with hospitalisation.

A study carried out by Lumley, Abeles, Melamed, Pistone and Johnson (1990) explored temperament as a predictor of the child's reaction to anaesthesia induction and the interaction between the child's temperament and the mother's behaviour displayed before the induction. The results showed that the child's temperamental characteristics of adaptability to change and of approaching versus withdrawing from novel stimuli were related to the child's coping mechanisms. The less adaptable and more withdrawing children were more distressed. A very recent study (Bonn, 1993) confirmed and expanded on Lumley et al's findings; 81 children were observed on the wards in Oxford hospitals and their mothers were asked to rate their children's temperaments. The children who coped less successfully with hospitalisation were rated by their mothers as being more moody, more resistant to change and more withdrawing.

It has been suggested by Rutter (1981), that intelligence may help children cope better with hospitalization because of their more mature conceptions of hospital and treatment. The study recently carried out by Bonn (1993) confirmed Rutter's suggestion. Eighty-one children between the ages of 3 and 6 were observed in hospital during the course of admission for acute asthma or ophthalmic surgery. It was found that the more intelligent children coped better both during high stress and low stress periods and were more compliant and more inquisitive about their medical condition.

\section{Preparation of children for hospitalisation.}

The idea that the psychological ill effects of hospitalisation may be alleviated by some sort of preparation increasingly is accepted. It has been suggested often that psychological distress in children is in part due to the fact that the child is unfamiliar with the routines, procedures and people which he/she may meet in a hospital ward. As a response to the 
hypothesis that vague, undefined threats due to unfamiliarity are more upsetting than threats that are known and understood, research has been developed to test the possibility that knowledge which implies predictability and feelings of control will decrease the deleterious effects of hospitalisation. Generally the research in this area focuses on paediatric patients admitted for short term hospital stays for minor surgery.

The usual methods employed to help children to cope with being hospitalized involve imparting information to them about their impending hospitalization (e.g. with pre-hospitalization tours, books and films) and about the medical procedures(e.g. pre-surgery preparation). In some cases in the United States, there are preparatory procedures that will tell the child what the operation procedure (e.g. tonsillectomy) will entail, for example with puppets. The question however remains: do these "preparatory methods" help?

A pioneering study in this field was carried out by Vernon (1973), who tried to prepare 6 year old children for anaesthesia induction. Half of the subjects saw a film that showed children responding calmly to anaesthesia induction. A control group saw no film. The rationale was that children would learn through modelling. Vernon reported that the children who saw the film exhibited less fear when confronted with their anaesthesia induction than the control group. Vernon and Bailey (1974) extended the previous findings by investigating children aged between 4 and 9 years. These children were undergoing minor elective surgery and the aim of the study was again to reduce the stress of the anaesthesia induction. The preparation film showed four children who were themselves undergoing anaesthesia induction. They saw the film with the investigator but without their parents. All the children's behaviours were rated by the anaesthetist and in addition by the investigators. Vernon and Bailey concluded that the children who had seen the film were less upset than the unprepared children both before and during induction. The anaesthetists' ratings of the children's behaviour during inductions however showed no differences between the two groups.

A better designed study by Melamed and Siegel (1975) investigated si xty children aged between 4 and 12 years. The children were hospitalised to undergo elective surgery for hernias, tonsillectomies or urinary tract difficulties. On hospital admission, half of these children were shown a preparatory film of a child being hospitalised and undergoing a hernia operation. The other hal fof the children were shown an unrelated control film. Both groups of children received extensive preparation by a nurse who explained to each child through pictures and demonstrations what would happen to her/him on the day of surgery. Each child was also visited by the surgeon and/or anaesthetist who explained to the child and his/her parents what his/her operation would involve. The group of children who saw the preparatory film had lower anxiety scores on a variety of measures and fewer post-hospital behaviour problems.

A study by Ferguson (1979) raises the question that a film may not be the best preparation for children, especially for older ones. Ferguson compared preparation carried out by (a) pre-admission home contact with a nurse and (b) a film shown on admission. The subjects were eighty two children, aged between 3 and 7 years, hospitalised for two days for elective tonsillectomy alone or in combination with adenoidectomy. Children in the pre-admission group were visited by a nurse five to seven days prior to admission and given general information about the hospital and more specific information about the operation and how the child might feel. The mothers were also given a hospital pamphlet. The children in the "film" group had no contact with hospital personnel prior to admission. On admission however they were shown a preparatory film " Yolanda and David have their tonsils out", while the other group were shown a non-related film. Ferguson (1979) found that undesirable post-hospital behaviour is most effectively diminished in the younger group ( 3 to 5 ) by the peer modelling film while the 6 to 7 year olds responded as positively to the pre-admission visit. The nurse visit was especially effective in decreasing maternal anxiety. This may be an important mediating variable because the mothers may help or hinder the children's efforts to manage their own anxiety.

Wol fer and Visintainer (1975) conducted an investigation of supportive nursing care at stress points during hospitalisation, of psychological preparation on children and of parents' responses to surgery. Eighty children aged 3 to 14 years and their parents were randomly assigned to either a control or experimental group. The experimental group received systematicpsychological preparation and supportive nursing care, while the control group received routine hospital care Measures of the children's responses included behavioural ratings as well as physical reactions such as pulse rates and ease of fluid intake. The parent's experience was measured by observations of behaviour and self-measures of anxiety. The results demonstrated that the children who received supportive nursing care showed less hospital upset and had fewer post-hospital adjustment problems. The parents of children in this group had lower self-ratings of anxiety and expressed greater satisfaction with care than the parents in the control group.

Another alternative is the preparation of children through play. Cassel and Paul (1967) used puppet play therapy for children hospitalised for cardiac catheterisation. Puppets and miniature equipment were used to demonstrate the procedures to the child. The preparation led to a decrease in disturbed behaviour during hospitalisation as well as an increase in expressed willingness to be admitted to hospital at a later date. Schwartz et al. (1983) also examined the effectiveness of play therapy in preparing a group of children for hospitalisation for dental operations. They compared the play presentation with two other groups: one receiving no pre-operative preparation and another receiving play therapy unrelated to hospital. They found that the group receiving hospital related play therapy showed increased co-operation and decreased upset.

A single case study of children aged 11 to 14 undergoing cancer chemotherapy has shown that their distress during venepuncture was considerably lessened by cue-controlled muscle relaxation, controlled breathing, pleasant imagery and positive self-talk (Dahlquist, Gil, Armstrong, Ginsberg and Jones, 1985).

Peterson and Ridley-Johnson (1980) surveyed all paediatric hospitals in the United States regarding their use of preparation techniques offered to hospitalised children. The majority of respondents were nurses and their reports showed that a large percentage of the paediatric hospitals utilized some formal pre-hospital preparation. Although some questionnaire respondents indicated that the hospital staff at large felt less positive about the preparation results, the majority indicated that the nurses in particular regarded the preparation of children as essential.

\section{Coping and Resilience}

So far in this paper hospitalisation has been regarded and discussed as a stressful event which frequently leads to diminished abilities and increased anxiety especially in younger children. But not all children react in the same way; for some children the experience of hospitalisation may even harden rather than weaken them. These children are often termed "invulnerable","stress-resistant" or just "resilient". Resiliency can be seen as the characteristic or ability to return rapidly to a previous psychological or physiological state (Rutter, 1987). Resilient individuals in a situation-to-situation basis respond rapidly, adjust and act. They tend not to "fall apart", overreact or underreact or react too slowly. Resilient children tend to respond more quickly and appropriately to major life events such as divorce of parents or hospitalisation.

Peterson (1989) has recently reviewed the research on coping styles children use during stressful medical procedures. This new research looks at the way children positively manage difficult experiences. Peterson concluded that most children can be characterized as adopting an active information-seeking style or else an avoidant or information-denying style. Several studies have revealed interesting aspects of these two coping styles. For example, Burstein and Meichenbaum (1979) found that information-seeking children who chose to play with medically-relevant toys later reported lower levels of anxiety after hospitalisation. Siegel (1981) extended this 
finding by showing that children who actively sought out medical information were more co-operative with medical staff and showed higher tolerance for pain than children who avoided information. Peterson (1989) concluded from her review that on a scale from active to avoidant coping: "the active end of the scale is associated with more beneficial responding to stressful events and improved psychological adjustment after discharge".

Hospitalisation can even be a positive experience for those children who successfully engage in and cope with the various risks accompanying the experience. Rutter's paper on resilience in children (1987) sheds new light on the contentious issue of the hospitalisation of children. He suggests that "protective factors" and "protective mechanisms" can change stressful experiences, such as hospitalisation, from a risk-inducing life event to one that "steels" children to make them more resilient when facing future stress. Rutter suggests that :"protection may lie in the 'steeling' qualities that derive from successful coping with the hazards when the exposure is of a type and degree that is manageable in the context of the child's capacities and social situation". To be able to overcome anxiety can enhance the self-esteem of the child. Moreover special relationships and attachments established by the child within the hospital settings (e.g. with a nurse) may not only provide her/him with essential psychosocial support but can also be positive social reinforcing experiences. It also seems likely that positive adaptive behaviour and coping is facilitated when the child is well supported by the parents. The parental mental state may be an important mediating factor in the child's response to hospitalisation.

\section{Conclusions}

This review of the literature on hospitalised children should bring some reassurance to clinicians and parents alike. Most children do not suffer permanent scars from a stay in hospital, but a significant proportion of them do experience some sort of behavioural or emotional disturbance. Moreover, prolonged or repeated hospitalisation increases the chance of later problems. It seems from the research so far that the immediate disturbance during hospital admission is due in part to the separation of the child from the people to whom he/she is attached. The presence on the ward of the mother/father or other familiar figures should be encouraged. A supportive relationship with a consistently present nurse reduces the emotional disturbance during hospital admission (Visintainer and Wolfer, 1975 ) but this is not the whole story. Hospitalisation is also stressful to the child for reasons that are intrinsic to hospital care and to medical and surgical treatment. The evidence on this point comes from the research findings showing that preparatory films, reading materials and pre-admission visits significantly lower the incidence of emotional disturbance during and immediately after discharge. Children vary in their capacity to cope with the experience of being hospitalised, younger children showing more distress. The intelligence and the temperament of the child also appear to act as moderating factors. Increased risk of problem behaviours is associated with coming from a psychosocially disadvantaged family. Children who adopt an active coping mechanism by seeking information and not denying fear are more co-operative with the hospital staff during their hospital stay and show less psychological upset after discharge.

\section{REFERENCES}

BONN, M., (1993). Temperament and its relationship to hospital behaviour in children. In preparation.

BOWLBY, J. (1951). Maternal Care and Mental Health. Geneva: World Health Organization.

BRAIN, D.J. \& MACLAY, I. (1968). Controlled study of mothers and children in hospital. British Medical Journal, 1,278-280.

BURSTEIN, S. \& MEICHENBAUM, D. (1979) The work of worrying in children undergoing surgery. Journal of Abnormal Child Psychology, 7, 121-132.

CAREY, W.B., FOX, M. \& MCDEVITT, S.C. (1977) Temperament as a factor in early school adjustment. Pediatrics, 60, 621-624.

CASSEL, S., \& PAUL, M.H.(1967). The role of puppet therapy on the emotional responses of children hospitalized for cardiac catheterization. Journal of Pediatrics, 71, 233-239.

COUTURE, C.J. (1976). The psychological response of young children to brief hospitalization and surgery: The role of parent-child contact and age. (Doctoral Dissertation. Boston University, 1976). Dissertation Abstracts International, 37.1427B

DAHLQUIST, L.M., GIL, K.M., ARMSTRONG, F.D., GINSBERG, A. \& JONES, B. (1985). Behavioral management of children's distress during chemotherapy. Journal of Behavior Therapy and Experimenual Psychiatry, 16, 325-329.

DAVENPORT, H.T. \& WERRY, J.S. (1970). The effect of general anesthesia, surgery and hospitalization upon the behavior of children. American Journal of Orthopsychiatry, 40, 806-824.

DOUGLAS, J.W.B. (1975). Early hospital admissions and later disturbances of behaviour and learning. Developmental Medicine and Child Neurology, 17, 456-480.
DUNN, J. (1980). Individual differences in temperament. In M.Rutter (Ed.), Scientific foundations of developmental psychiatry. London: Heinemann.

GOLDSMITH, H.H., BUSS, A.H., PLOMIN, R., ROTHBART, M.K., THOMAS,A., CHESS, S., HINDE, R.A. \& MCCALL, R (1987). Roundtable: what is temperament? Four approaches. Child Development,58, 505-529.

FERGUSON, B.F. (1979). Preparing young children for hospitalization: A comparison of two methods. Pediatrics, 64, 656-664.

ILLINGWORTH, R.S. \& HOLT, K.S.(1955). Children in hospital: Some observations on their reactions with special reference to daily visiting. Lancet, 269, 1257-1262.

KATZ, E.R., KELLERMAN, J. \& SIEGEL, S.E. (1980). Behavioral distress in children with cancer undergoing medical procedures: Developmental considerations. Journal of Consulting and Clinical Psychology, 48, 356-365.

KEOGH, B.K. \& PULLIS, M.E. (1980) Temperamental influences on the development of exceptional children. Advances in Special Education, 1, 239-276.

LUMLEY, N.A., ABELES, L.A., MELAMED, B.G., PISTONE, L.M. \& JOHNSON, J.H. (1990). Coping outcomes in children undergoing stressful medical procedures: The role of child- environment variables. Behavioral Assessment, 12, 223-238.

MCGILLICUDDY, M.C. (1976). A study of the relationship between mothers' rooming-in during their children's hospitalization and changes in selected areas of children's behavior. (Doctoral Dissertation. New York Univerity, 1976). Dissertation Abstracts International, 37, $700 \mathrm{~B}$.

MELAMED, B.G. (1977). Psychological preparation for hospitalization. In $\mathrm{S}$. Rachman (Ed.), Contributions to medical psychology. New York: Pergamon Press.

MELAMED, B.G., MEYER, R., GEE, C. \& SOULE, L. (1976) The influence of time and type of preparation on children's adjustment to hospitalization. Journal of Pediatric Psychology, 1, 31-37.

MELAMED, B.G. \& SEIGEL, L.J. (1975). Reduction of anxiety in children facing hospitalization and surgery by use of filmed modelling. Journal of Consulting Clinical Psychology, 43, 511-521.

PETESON, L. (1989). Coping by children understanding stressful medical procedures: Some conceptual, methodological and therapeutic issues. Journal of Consulting and Clinical Psychology, 57, 380-387. 
PETERSON, L. \& RIDLEY-JOHNSON, R (1980). Pediatric hospital response to survey on pre-hospital preparation for children. Journal of Pediatric Psychology, $5,1-7$.

PLATT REPORT (1959). The Welfare of Children in Hospitals. London: HMSO

QUINTON, D. \& RUTTER, M. (1976). Early hospital admissions and later disturbances of behaviour: an attempted replication of "Douglas" findings. Developmental Medicine and Child Neurology, 18, 447-459.

ROBERTSON, J. (1958). Young Children in Hospitals. New York: Basic Books

RUTTER, M. (1967). A children's behaviour questionnaire for completion by teachers: Preliminary findings. Journal of Child Psychology and Psychiatry, 8, 1-11.

RUTTER, M. (1981). Stress, coping and development: Some issues and some questions. Journal of Child Psychology and Psychiatry, 22, 323-356.

RUTTER, M. (1987). Psychosocial resilience and protective mechanisms. American Journal of Orthopsychiatry, 57,316-331.

SCHWARTZ, H.B., ALBINO, J.E. \& TEDESCO, L.A. (1983). Effects of psychological preparation on children hospitalized for dental operations. Joumal of Pediatrics, 102, 634-638.
SIEGEL, L.J. (1981). Naturalistic study of coping strategies in children facing medical procedures. Paper presented at the meeting of the Southeastern Psychological Association, Atlanta, USA.

SYLVA, K., BONN, M., STEIN, A. \& DUDLEY, L. (1993). Children's coping with hospitalisation: The influence of age, intelligence and gender. Submitted to the Journal for Child Psychology and Psychiatry.

VERNON, D.T.A. (1973). Use of modeling to modify children's responses to a natural potentially stressful situation. Journal of Applied Psychology, 58, 351-355.

VERNON, D.T.A. \& BAILEY, W.C. (1974). The use of motion pictures in the psychological preparation of children for induction of anesthesia. Anesthesiology, $40,68-72$

VERNON, D.T.A., FOLEY, J.M. \& SCHULMAN, J.L. (1967). Effect of mother-child separation and birth order on young children's responses to two potentially stressful experiences. Journal of Personality and Social Psychology, 5, 162-174.

VERNON, D.T.A., SCHULMAN, J.L. \& FOLEY, J.M. (1966). Changes in children's behavior after hospitalization: Some dimensions of response and their correlates. American Journal of Diseases in Children, 111, 581-593.
VISINTAINER, M.A. \& WOLFER, J.A. (1975). Psychological preparation for surgical pediatric patients: The effect on children's and parents' stress responses and adjustment. Pediatrics, 56, 187-202.

\section{FOOTNOTE}

Most of the work reviewed in this article was done in the United Kingdom or in America. The conclusions drawn from these investigations should therefore be applied in the South African context with caution. The majority of South African children bave a very different life experience from American or British children and therefore hospitalisation may mean something different for them. However, until more research in the field is carried out locally, we may have to draw, albeit with care, on the findings from abroad.

$$
\begin{gathered}
\text { Marta Bonn } \\
\text { Ph.D. Psychology }
\end{gathered}
$$

Institute for Behavioural Sciences UNIVERSITY OF SOUTH AFRICA 